DARIUSZ ANDRZEJ SIKORSKI

Instytut Historii

Uniwersytetu im. Adama Mickiewicza

w Poznaniu

\title{
O TYM, JAK METODOLOG HISTORII STARA SIĘ ZATUSZOWAĆ SWOJE POTKNIĘCIA O ANTROPOLOGIĘ HISTORYCZNA. (W ODPOWIEDZI KAROLINIE POLASIK-WRZOSEK)
}

Karolina Polasik-Wrzosek odpowiedziała na moją recenzję jej książki, starając się udzielić mi przy okazji kilku lekcji. Próbę tę przyjmuję z dobrą wiarą, gdyż nauki nigdy dość, a lektura jej tekstu rzeczywiście była dla mnie pod wieloma względami bardzo interesująca ${ }^{1}$. Ponadto głos K. Polasik-Wrzosek ujawnia - być może wbrew jej intencjom - problemy związane z miejscem metodologii historii w badaniach historycznych. Stwarza to okazję do poruszenia kilku z nich.

Zdecydowana większość tekstu poświęcona jest próbie wykazania mojej niekompetencji zawodowej przez sugerowanie, że prezentuję poglądy wręcz absurdalne. Jednak Autorka polemizuje zasadniczo z poglądami, których nie wygłaszałem, a które mi przypisuje. Wokół nich rozwija większość swojego tekstu. Nie mam zatem powodu, aby podejmować dyskusję w obronie nie moich, a jedynie mi przypisywanych poglądów, które w kształcie podanym przez Autorkę rzeczywiście są najczęściej absurdalne. Niestety będę musiał sporo miejsca poświęcić na wykazanie specyficznej metody polemiki zastosowanej przez Autorkę ${ }^{2}$.

${ }^{1}$ K. Polasik-Wrzosek, Jak historyk potyka się z metodologia historii, KH 120, 2013, 2, s. 327-349. Jeśli nie zaznaczono inaczej, podane w tekście numery stron w zakresie 1-134 dotyczą recenzowanej książki (K. Polasik, Antropologiczny rekonesans historyka. Szkice o antropologii historycznej, Bydgoszcz 2007), w przedziale 485-510 mojego artykułu recenzyjnego (D. A. Sikorski, Jak historyk potyka się o antropologię historyczna, KH 118, 2011, 3, s. 485-510), a w zakresie 327-349 cytowanego wyżej tekstu K. Polasik-Wrzosek.

${ }^{2}$ Jako nic nie wnoszące do meritum sprawy pomijam tu wątki, w których K. Polasik-Wrzosek skupia się na analizowaniu mych wad wszelakich, jakie zdiagnozowała przy okazji lektury mojego tekstu, i epitetów, którymi mnie określa. Godzę się z tym, 
Wobec jednoznacznego oświadczenia K. Polasik-Wrzosek „nie uprawiałam i nie uprawiam zawodu historyka" (s. 329) przyjmuję do wiadomości, że K. Polasik-Wrzosek nie jest historykiem. Sądzę jednak, że usprawiedliwia mnie w tej pochopnej, jak się okazuje, ocenie jej jako historyka uzyskanie przez Autorkę magisterium oraz doktoratu z historii w Instytucie Historii UAM (specjalność metodologia historii) na podstawie recenzowanego tekstu. Ponadto w swojej książce sama siebie określiła jako historyka: „wszystko co jako historyk [podkr. - D. A.S.] mogłabym tu powiedzieć, dla specjalistów zbliżałoby się do banału" (s. 8). Jeśli dzisiaj Autorka nie życzy sobie być historykiem, to nie mam powodu tego kwestionować. $Z$ drugiej strony ta deklaracja, mimo wszystko, rzuca nowe światło na przygotowanie Autorki do zajmowania się historią (nawet jako metodolog historii), także jeśli jest to antropologia historyczna, która przecież - również jej zdaniem - jest historią.

Konkluzja odpowiedzi Autorki jest krótka: „z wszystkim nie zgadzam się zasadniczo" (s. 327). Autorka nie zgadza się także z tym fragmentami, w których wyrażam się o niej pozytywnie, np. doceniając jej uczciwość naukową pod względem cytowania prac jedynie przeczytanych i zaznaczanie - jeśli już cytuje - tych znanych jej z drugiej ręki. Autorka traktuje to nad wyraz podejrzliwie, uznając, że to z mojej strony tylko chwyt retoryczny mający wzmocnić w czytelniku negatywny wydźwięk całości omówienia ${ }^{3}$. Podobnie uznanie, że wytyczony przez Autorkę cel pracy jest ,ambitny i wyjątkowo interesujący”, potraktowała jako „protekcjonalną opinię" (s. 328), przy okazji bardzo wątpiąc w moją możliwość osą$\mathrm{du}$, co jest dla mnie interesujące lub nie jest. Rozumiem, że Autorka nie zgadza się także z tą częścią mojej krytyki jej książki, która oparta jest na opiniach szerokiego grona badaczy, na których się powołuję.

Moja opinia, że w sytuacji,kiedy antropologia historyczna nie budzi zainteresowania szerszego grona historyków,,,cieszyć powinna [podkr.D.A.S.] każda szerzej zakrojona próba przedstawienia problemu i korzyści płynących z zastosowania perspektywy antropologicznej w badaniach historycznych" (s.485), wywołała u Autorki gwałtowne oburzenie: jak moge

że skoro tak, a nie inaczej mnie osądza, to tak mnie widzi i jej poglądy dotyczące mnie osobiście przyjmuję do wiadomości.

${ }^{3}$ Ponoć popadłem w sprzeczność w pochwale, gdyż wytknąłem - jak sądzi - pozorny cytat (s. 329), ale nie zauważa, że sama wcześniej stwierdza, iż pracę tę (art. Leonarda Boyle'a) zna z drugiej ręki (za pośrednictwem wzmianki Aarona Guriewicza). Ja tylko podkreśliłem, idąc za jej oświadczeniem, że jedyna recenzja krytyczna (w sensie, że w ogóle jakaś krytyczna była) wobec książki Emmanuela Le Roy Laduriego (20 stron) znana jest jej wyłącznie z drugiej ręki - uwypukliłem jedynie fakt przez samą Autorkę potwierdzony. 
cieszyć się „z góry” na jej książkę, skoro tekst recenzji roi się od zarzutów (s. 328). Chyba żaden czytelnik mojego tekstu nie odniósł wrażenia, że lektura książki sprawiła mi radość, gdyż jej tekst -6 arkuszy autorskich na podstawie 54 publikacji ${ }^{4}$ - bez wątpienia jest „szerzej zakrojoną próbą przedstawienia problemu", ale nie jest - w świetle opinii wyrażonej i uzasadnionej przeze mnie w recenzji - jej udaną realizacją. Natomiast prawie każda publikacja, także zła, coś wnosi do konkretnego problemu, choćby przez to, że dobitnie ilustruje jakieś zjawisko w historiografii lub wywołuje dyskusję.Jedne niewiele (lub nawet wcale) przyczyniają się do postępu naszej wiedzy, inne więcej, a nawet bardzo wiele. Książka Autorki była jedynie pretekstem dla mnie do przedstawienia pewnego fragmentu dyskusji nad antropologią historyczną na przykładzie recepcji dwóch analizowanych przez Autorkę książek. K. Polasik-Wrzosek robi mi przytyk, że sam do krytyki książki o Montaillou nic nie wnoszę i - co zaskakujące przy jej całkowitej nieznajomości literatury narosłej wokół monografii o Montaillou „biorę w ciemno dawne i najnowsze opinie krytyczne” (s.334). Tu ma rację, rzeczywiście nic nie wnoszę (podobnie jak do książki Carla Ginzburga), bo moim zamiarem było jedynie przedstawienie po raz pierwszy w polskiej literaturze - recenzję książki wykorzystałem jako okazję - całościowej dyskusji nad obiema książkami, które cieszą się u polskiego czytelnika do dziś dużym zainteresowaniem. Tym bardziej że odgrywają znaczącą rolę w dydaktyce uniwersyteckiej, a opinie wyrażane o nich w polskim środowisku są rażąco odstające od rzeczywistego ich odbioru w historiografii światowej.Jak rozumiem, właśnie ten aspekt mojego tekstu skłonił redakcje „Kwartalnika Historycznego” do przyjęcia do druku recenzji z pominięciem własnej zasady, iż recenzje publikuje się z prac wydanych w ciągu trzech poprzednich lat. Pragnę zauważyć, że omówienie to zajmuje aż $60 \%$ tekstu, tylko pozostała część poświęcona jest książce K. Polasik-Wrzosek. Oczywiście obie części są ze sobą związane, gdyż tekst Autorki - moim zdaniem - doskonale ilustruje zjawisko, które doprowadziło do tego, że analizowane przez Autorkę dzieła funkcjonują w pewnych środowiskach historyków, a zwłaszcza metodologów historii, jakby w oderwaniu od stanu historiograficznej dyskusji nad nimi.

Wyraziłem swoje zastrzeżenia co do trafności ujęcia początków antropologii historycznej przez Autorkę i na nic się zda zasłanianie rzekomo

${ }^{4}$ Nie ma podstaw, żeby uznać, że zakres wywodów Autorki w jakiś sposób był ograniczony np. wymogami wydawniczymi, gdyż tekst drukowany jest niemal identyczny z tekstem będącym podstawą przewodu doktorskiego, w którym żadne ograniczenia objętościowe nie obowiązują. Zatem to, co czytelnikowi zostało przedstawione w książce, ma formę i treść odpowiadającą intencjom Autorki, a nie jest wynikiem kompromisu np. z wydawcą. 
„rekonesansowym” charakterem książki ${ }^{5}$, gdyż o zamieszczeniu zarysu w takiej skromnej postaci zadecydowała sama Autorka. Mam chyba prawo, jak każdy czytelnik, różnić się z Autorką co do sposobu ujęcia problemu oraz wyboru poruszanych wątków. Swoje uwagi opatrzyłem uzasadnieniem wspartym dość szeroką literaturą, do której Autorka się nie odnosi. W odpowiedzi Autorka przedstawia problem początków antropologii historycznej w sposób, który ma sprawić, by czytelnik odniósł wrażenie, że moje uwagi o nietrafnym ujęciu kwestii początków są nie tylko nieuzasadnione, ale po prostu niedorzeczne. Obecnie K. Polasik-Wrzosek stara się wmówić czytelnikowi, że od początku jej zamiarem było oddanie w tekście rozwoju antropologii historycznej w historiografii francuskiej i dlatego nie przedstawiła innych nurtów i źródeł inspiracji. Autorka wyznaje swoją „skłonność do szukania początków antropologii historycznej w tradycji myśli francuskiej” (s.344), ale co to ma do rzeczy skoro - zgodnie z jej deklaracją ze wstępu (s. 7) - książka poświęcona jest „związkom historii z antropologią widzianym jako rodzaj poznawczego rozpoznania terenu" bez jakichkolwiek ograniczeń. Autorka we wprowadzeniu zakreśliła jeden z celów: „Próbuję zatem nakreślić niektóre drogi prowadzące do zbliżenia historii i antropologii [- ] skutkiem tego zbliżenia jest nurt zwany antropologią historyczną" (s. 8). Tu, jak i w dalszej części wstępu nie ogranicza swoich dociekań do antropologii historycznej historyków francuskich. Gdyby zresztą tak było, to książka Ginzburga (oryginalne wydanie 1976) nie mogłaby ilustrować francuskiej myśli w zakresie antropologii historycznej. Uzasadnione zatem jest wyniesione ze wstępu wrażenie, że zamiarem Autorki było jednak zarysowanie całościowego zjawiska, które nazywa „zbliżeniem historii i antropologii”, bez ograniczania się do historyków francuskich. Zatem czytelnik, tak jak ja to zrobiłem, ma chyba prawo zapytać o „zbliżanie antropologii i historii”, jakie dokonywało się poza historiografią francuską, w tym także zakresie również na gruncie historiografii amerykańskiej. Jeżeli Autorka uznaje książkę Ginzburga za arcydzieło antropologii historycznej, to dlaczego całkowicie pomija ten kierunek chociażby w historiografii włoskiej - Ginzburg nie był we Włoszech odosobniony (np. Giovanni Levi ${ }^{6}$, Carlo Poni).

${ }^{5}$ Użyte w tytule słowo „rekonesans” odnosi się do historyków uprawiających antropologię historyczną, a nie do zamierzeń Autorki (por. s. 7-8).

${ }^{6}$ Por. opinie K. Zamorskiego, 0 doświadczeniach we wdrażaniu specjalizacji ,, antropologia historyczna" w programie studiów historycznych $w$ Instytucie Historii UJ, w: Historia dziś. Teoretyczne problemy wiedzy o przeszłości, red. E. Domańska, R. Stobiecki, T. Wiślicz, Kraków 2014, s. 169: „Jestem pełen nadziei, że uda mi się przełamać kultowość Sera i robaków na rzecz Il benandanti" i rolę G. Leviego (s. 167). 
W odpowiedzi na moje zarzuty Autorka swoją koncepcję genezy antropologii historii nieco rozszerza (s. 340-342), ale niech nie robi mi wyrzutów z tego powodu, że jej wywód uznałem za bardzo powierzchowny! Wbrew twierdzeniu Autorki (s.344) nie uznaje, że antropologia historyczna jest "Made in USA" i nie sugeruję (gdzie?), że jej amerykańska wersja inspirowała Autorów Montaillou czy książki o młynarzu Menocchio. Wskazuję jedynie, że koncept antropologii historycznej u badaczy amerykańskich sięgał do innych korzeni i doświadczeń, że historycy amerykańscy zbliżali się do antropologii historii swoją własną drogą. Dopiero w latach osiemdziesiątych XX w. antropologia historyczna we Francji zaczęła wpływać na punkt widzenia badaczy amerykańskich (i vice versa). Skoro Autorka starała się pokazać drogi zbliżeń antropologii i historii (rozdz. 1), to zrobienie tego bez wątku amerykańskiego jest chybione. Stąd też mój zarzut, że Autorka, sugerując wyjątkową rolę historiografii francuskiej, zniekształca to, co wiemy o inspiracjach historyków antropologią kulturową ${ }^{7}$. I tyle.

Autorka dobitnie podkreśla, że nie ma problemu ze wskazaniem, czym jest antropologia historyczna. Lektura jej odpowiedzi przekonała mnie, że ma takie głębokie przekonanie. Co nie zmienia sytuacji, że nie znajdziemy w książce ani w jej odpowiedzi żadnego wyjaśnienia, czym jest - zdaniem K. Polasik-Wrzosek - antropologia historyczna. Jedyna wskazówka to to, że „tytuły prac i ich tematyka są z perspektywy tradycyjnego historyka i zwyczajnego odbiorcy egzotyczne, dziwne czy nawet dziwaczne" (s. 14), czego przykładem może być podtytuł książki Ginzburga „,wizja świata pewnego młynarza z XVI wieku". Gdy zwróciłem uwagę, że gdyby oceniać prace historyczne po tytułach, to „wizja świata” jest zadomowionym tematem tradycyjnej historiografii, tyle że Autorce nieznanej (s. 487 n.), w replice Autorka zasugerowała, że można wskazać wiele znamienitszych rozpraw nad mentalité, z czym się zgadzam..., ale sprawa dotyczyła osądzania książek wedle tytułów - od tego K. Polasik-Wrzosek rzecz zaczęła, ja tylko wykazałem, że brak w tym sensu.

Zgadzam się też z tym, że ja „mam problem” z antropologią historyczną. I nie pociesza mnie nawet to, że wielu wybitnych zarówno antropologów, jak i historyków ma podobny problem. Jacques Le Goff, definiując

${ }^{7}$ Na przykład w swym dziele Le Carnaval de Romans. De la Chandeleur au mercredi des Cendres 1579-1580 (Paris 1979), powstałym niedługo po Montaillou, Emmanuel Le Roy Ladurie odwołuje się wprost do prac antropologów brytyjskich: Victora Turnera, Edmunda R. Leacha, Maxa Gluckmanna oraz uznawanego za jednego z prekursorów antropologii historycznej Edwarda P. Thompsona. Źródła inspiracji nazywa wprost: „L'analyse de l'anthropologue anglais s'applique bien au Carnaval de Romans” (s. 339), chociaż odwołuje się również do antropologów francuskich, takich jak Marc Augé i Arnold van Gennep. 
w 2004 r. przedmiot badań Autorki, stwierdził, że „antropologia historyczna to badanie ewolucji ludzkich społeczeństw", w której można wyróżnić trzy zasadnicze aspekty: nakierowanie na człowieka, holizm i przemiany ${ }^{8}$. Z powodu braku dwóch ostatnich cech mikrohistoria, a zatem „mistrzowska" jej realizacja w monografii o friulańskim młynarzu Ginzburga - będąca zdaniem Autorki także mistrzowską reprezentacją antropologii historycznej - została przez Le Goffa expressis verbis nie tylko z tego kierunku wyłączona, ale uznał on sam koncept mikrohistoryczny za przelotny romans kilku historyków, bez widoków na dłuższy związek ${ }^{9}$. Z pewnością książka o Montaillou nie odpowiada wizji antropologii historycznej Le Goffa (przynajmniej tej z 2004 r.) ze względu na statyczność obrazu, gdyż tenże od lat siedemdziesiątych podkreślał, że celem antropologii jest uchwycenie dynamiki ewolucji kultury, a nawet badacze ujęci wizją Montaillou pióra Emmanuela Le Roy Laduriego zauważali, iż obraz jest statyczny, że autor pokazał społeczeństwo zamrożone w czasie ${ }^{10}$. Zatem Le Goff, autorytet Autorki w zakresie antropologii historycznej, tych dwóch książek jako „arcydzieł” gatunku z pewnością by ze sobą nie zestawił. Mogę więc chyba mieć własne powody, dla których wątpię w antropologiczną „zawartość” książki Ginzburga, jak i Le Roy Laduriego, tym bardziej, że podaję uzasadnienie, do którego Autorka się w ogóle nie odnosi - do potępienia mnie wystarcza jej już sam fakt, iż odmawiam tym książkom miana ,antropologicznych” i śmiem „atakować autorów renomowanych prac” (s. 327) (pomijam, że nie atakuję autorów, ale krytykuję ich dzieła).

Dobrze się K. Polasik-Wrzosek domyśla, że również nie widzę „przejawów strategii badawczej zwanej antropologią historyczną" u Aarona Guriewicza i Le Goffa, mimo że z antropologią historyczną obaj jednoznacznie się utożsamiali. Wprawdzie kwestia stosunku tych dwóch badaczy do antropologii nie była przedmiotem mojego zainteresowania w recenzji, bo nie była też poruszana w książce, to według mnie uzasadnienie przez nich podawane jest niewystarczające ${ }^{11}$. Zadaniem metodo-

${ }^{8}$ P. Rodak, Pismo, książka, lektura. Rozmowy: Le Goff, Chartier, Hébrard, Fabre, Lejeune, Warszawa 2009, s. 33 n., 41 n.

${ }^{9}$ Ibidem, s. 46.

${ }^{10}$ Ibidem, s. 42.

${ }^{11}$ A. Guriewicz, Historia i antropologia historyczna, „Konteksty. Polska Sztuka Ludowa” 1997, s. 13-20; por. krytykę analizy antropologicznej źródeł średniowiecznych przez Dietera Harmeninga, Aus „tieferer Schicht des Volksbewußtseins”. Quellenkritische Anmerkungen zu Aaron J. Gurjewitsch: „Mittelalterliche Volkskultur”, „Bayerisches Jahrbuch für Volkskunde" 1994, s. 137-150; odp. A. Guriewicza, ibidem, 1996, s. 189-190; omówienie dyskusji dostępne po francusku: D. Harmening, Anthropologie historique ou herméneutique littéraire? Une critique ethnographique des sources médiévales, „Ethnologie française" 27, 1997, 4, s. 445-456. 
logii historii jest również analizowanie, czy deklaracje metodologiczne historyków są uzasadnione i czy mają pokrycie w ich praktyce. Po prostu nie zgadzam się z próbami fundowania antropologii historycznej głównie na podstawie rzekomo antropologicznych tematów poruszanych w pracach „antropologizujących" czy posługiwania się przez historyków antropologicznym rozumieniem kultury (tę ostatnią wersję propaguje Wojciech Piasek). Uważam, że istotne są jedynie inspiracje metodami badawczymi antropologii kulturowej, a te pojawiają się w literaturze historycznej o wiele rzadziej, oraz doświadczenia badawcze antropologów kulturowych, które mają na tyle istotny wpływ na poznanie historyczne, że bez ich uwzględnienia nasza wiedza o przeszłości - zarówno w wymiarze konkretnych problemów badawczych, jak i ujęć ogólnych - byłaby uboższa. Jako przykład pracy rzeczywiście - moim zdaniem - opartej na metodzie antropologicznej podałem (wraz z uzasadnieniem) monografię Karola Modzelewskiego, Barbarzyńska Europa. Na to Autorka zbywająco odpowiada, że tu ,zaskoczyłem powierzchownością”, jednak ani jednym zdaniem nie wykazując, w czym się myliłem i dlaczego tę propozycję odrzuca.

Stwierdzeniem, że „Zdaniem Sikorskiego Le Goff, ponieważ nie deklarował w Naissance du Purgatoire z 1981 r. swej przynależności do nurtu antropologii historycznej, to nie identyfikował się z taką postacią historycznego badania" (s.347) - inicjuje Autorka swój kolejny wywód mający pokazać absurdalność moich poglądów. Jednak niczego takiego nie napisałem. Jedyny moment, w którym odnoszę się do książki Le Goffa o czyśćcu (łącznie z pracą Guriewicza na ten temat), to ten, kiedy zwracam uwagę na nieadekwatność przykładu przywołanego przez Autorkę, twierdzącą, iż „Badacze reprezentujący nurt antropologii historycznej podjęli wiele oryginalnych, spektakularnych aspektów naszej przeszłości" (s. 26), i jako ilustrację tej tezy podającą dwie monografie o czyśćcu autorstwa obu badaczy. Problem ten (czyśćca) był podejmowany w historiografii od XIX w. i nie jest wynalazkiem antropologii historycznej, o czym - jak wskazałem - mogła się przekonać, przeglądając choćby bibliografię w książce Le Goffa. Tylko tyle.

Właśnie na problem ze zdefiniowaniem antropologii historycznej wskazywałem jako na zasadniczy w rozważaniach nad tym kierunkiem historiografii. Autorka zbyła to słowami: „Sikorski oferuje bez namysłu cały zespół tekstów zawierających jakoby definicje (sic!) antropologii historycznej (patrz s. 491, p. 17), przyjmując, że ethnohistory to zawsze to, o co chodzi w antropologii historycznej" (s. 344 n.). Gdyby Autorka przeczytała cytowane przeze mnie prace, to właśnie znalazłaby liczne próby zdefiniowania antropologii historycznej, tak jak każdy z cytowanych autorów ją pojmował. Właśnie mnogość tych prób i znaczne rozbieżności między nimi pokazują, że nie ma konsensusu co do tego, czym antropologia historyczna jest. 
Gdyby przeczytała, to dowiedziałaby się też, że jeśli dany autor przed czterdziestu bądź trzydziestu laty posługiwał się terminem etnohistoria, to nie musiał mieć na myśli czegoś odmiennego od tego, co obecnie rozumiane jest jako antropologia historyczna ${ }^{12}$. Le Goff, który przyczynił się do upowszechnienia terminu ,antropologia historyczna”, sam stwierdził, że „je parlerais plus volontiers d'anthropologie historique que d'ethnohistoire, je remarque toutefois que si les historiens - certains historiens ont été séduits par l'ethnologie parce qu'elle mettait en avant la notion de différence, dans le même temps les ethnologues s'orientent vers une conception unifiée des sociétés humaines, voire vers le concept d'homme que l'histoire, aujourd'hui comme hier, ignore"13. E. Le Roy Ladurie w rzeczonej książce mówi o „etnografii pasterskich Pirenejów”"14.

Deklarację Autorki: „moje analizy zjawiska antropologizowania historii [--] dowodzą, że mimo tak przemożnego wtargnięcia problematyki antropologicznej do historii, ta ostatnia nie przestała nią być. Powszechnie uważa się przecież, że są to dzieła [Ginzburga i Le Roy Laduriego D. A. S.] czy nawet arcydzieła historyczne" (s. 129), skomentowałem, że „,jeśli tak, to nie tylko wspomniane historiograficzne majstersztyki, ale i praca samej K. Polasik powinny zostać poddane zwykłemu osądowi historyka, wedle kryteriów i zasad typowych dla metody i krytyki historycznej" (s. 486). Skoro dzieła obu autorów są pracami historycznymi co do tego się z pewnością Autorka zgodzi - to i praca Autorki o nich jako o dziełach historiograficznych, ilustrujących pewne zjawisko w historiografii, podejmuje tematykę z historią jak najściślej związaną. Autorskie „wprowadzenie” (rozdz. 1) ma charakter historycznego zarysu antropologii historycznej, nie mówiąc o deklarowanych „wątkach ogólnohistorycznych".

Mam zatem powody, by sądzić, że książka podejmuje problematykę z zakresu historii historiografii - tu antropologii historycznej - a historia historiografii jest ciągle (jeszcze) historią, co sama Autorka potwierdza: „Badacze historiografii, tak jak inni historycy” (s. 15). Autorka, broniąc swego stanowiska, postanowiła przypisać mi kilka absurdalnych poglądów, które wyśmiewa - zresztą słusznie (s. 335 nn.).

Autorka odmawia mi prawa jako historykowi (a w konsekwencji innym historykom również) do podjęcia dyskusji z jej opiniami o antropologii historycznej i dwiema książkami, które z całą pewnością są książkami historycznymi. Narzuca się pytanie: kto w takim razie jest jej zdaniem upoważ-

${ }^{12}$ E. Domańska, Posłowie. Historia antropologiczna. Mikrohistoria, w: N. Z. Davis, Powrót Martina Guerre'a, Poznań 2011, s. 198 nn.

${ }^{13}$ J. Le Goff, Pour un autre Moyen Age, Paris 1978, s. 9.

${ }^{14}$ E. Le Roy Ladurie, Montaillou, wioska heretyków 1294-1324, Warszawa 1988, s. 130. 
niony do takiej dyskusji? Kto ma prawo podejmować dyskusję w sprawie antropologii historycznej?

Wywody Autorki do s. 336 (w tym i wcześniejsza „ucieczka” z cechu historyków) zmierzają do tego, żeby przekonać czytelnika, że recenzowana książka nie została napisana przez historyka, nie jest pracą historyczną, zatem nie może być analizowana przez historyka, czyli mnie, bo jest... „pracą metodologiczną” lub „interpretacja moja jest taka, jaka jest, bo jest czyniona na modłę metodologi i historii [podkr.-D.A.S.]" (s.336). Zatem „bez kwalifikacji zawodowych” nie mam po prostu prawa tej książki oceniać15. Czy Autorka nie zapomniała aby, że obaj wyróżnieni przez nią autorzy nie byli metodologami historii, a ich nowe dla historiografii propozycje - tak jak widzi to Autorka - wyrastały z doświadczeń pracy historyka nad konkretnym zagadnieniem badawczym?

Autorka często odwołuje się do rzekomych analiz metodologicznych przeprowadzanych w jej książce, ale praca ma charakter wyłącznie deskryptywny, a nie analityczny. Nawet gdyby w książce znajdowały się jakieś analizy metodologiczne, to i one mogłyby być przedmiotem refleksji historyka. Od początku uprawiania historii jako nauki metodologia historii była rozwijana głównie przez historyków, a znaczące rozprawy metodologiczne, które ukazały się do drugiej połowy XX w., są wynikiem autorefleksji właśnie historyków nad własną pracą. Ta tradycja trwa do dzisiaj, chociaż coraz częściej historia jest obiektem analiz metodologicznych dokonywanych przez badaczy nie będących historykami, nie prowadzących badań historycznych, a co gorsza, nie znających podstaw warsztatu pracy historyków. Zatem, gdy napisałem, że książka ta „powinna być poddana zwykłemu osądowi historyka wedle kryteriów i zasad typowych dla metody i krytyki historycznej” (s. 486), mogłem mieć tylko tę tradycję na myśli. Gra słowami, którą uprawia Autorka, ma na celu odwrócenie uwagi od istoty sprawy.

Być może Autorka jako niehistoryk nie wie, że przedmiotem krytyki naukowej prowadzonej przez historyków są również zagadnienia metodologiczne, jednak fakt ten powinien być znany Autorce jako metodologowi historii. Gdy historycy polemizują ze sobą o wartości poznawczej źródeł w ogólniejszym aspekcie, często poruszają się w sferze metodologii, gdy

${ }^{15} \mathrm{~W}$ bazie gromadzącej oficjalne dane MNiSW o kwalifikacjach zawodowych pracowników nauki (http://nauka-polska.pl/shtml/raporty/raporty_ludzie.shtml) moje kwalifikacje zostały następująco określone: „doktor habilitowany nauk humanistycznych w zakresie historii, specjalności: historia średniowiecza, historia historiografii, metodologia historii, antropologia historyczna". W przypadku K. Polasik-Wrzosek: „doktor nauk humanistycznych w zakresie historii, specjalności: metodologia historii, historia historiografii, antropologia historyczna". 
analizują sposoby wnioskowania, gdy starają się uchwycić konkretną pracę na tle rozwoju badanego problemu czy samej historii jako dyscypliny, to nieuchronnie wkraczają na pole metodologii historii. Autorka zdaje się nie zauważać, że kwestie metodologiczne są często obecne w tekstach historyków, będąc przedmiotem debat w pracach o tematyce ściśle historycznej ${ }^{16}$. Oczywiście tematyka ta ogranicza się do kwestii najbardziej interesujących historyków i z tego powodu w pracach o charakterze historycznym problematyka związana $\mathrm{z}$ metodologią historii nie jest podejmowana w sposób systematyczny, ale bywa obecna.

Stanowisko Autorki odzwierciedla zjawisko dość niepokojące z punktu widzenia historyków, mianowicie chęć zacieśnienia grupy badaczy mogących dyskutować na temat prac z zakresu metodologii historii (zwłaszcza gdy dyskusje przynoszą krytyczne wnioski) wyłącznie do tych osób, które uzyskają coś w rodzaju akceptacji środowiska metodologów historii.Jednocześnie przedstawiciele tego środowiska dość często wypowiadają się na temat prac - także w ich mniemaniu - ściśle historycznych w sposób nadmiernie autorytatywny (niezależnie, czy pochlebnie, czy krytycznie) w stosunku do swej dość skromnej znajomości historiografii, używanych przez historyków metod badawczych etc., nie mówiąc już o znajomości samych problemów badawczych, które są podejmowane w pracach będących przedmiotem metodologicznej refleksji. W pewien sposób niektórzy metodolodzy czują się zwolnieni nie tylko z opanowania umiejętności niezbędnych każdemu historykowi (czego osobiście bym nie wymagał), ale nawet $\mathrm{z}$ wiedzy o tych umiejętnościach (a tego się domagam) ${ }^{17}$. Dają przy tym wielokroć dowody, że nie znają przedmiotu swoich refleksji, co powoduje z drugiej strony, tzn. praktykujących historyków, równie niepokojącą tendencję, mianowicie ignorowanie wszelkich rozważań metodologicznych wybiegających poza bezpośrednio użyteczne w pracy naukowej zagadnienia, a nawet uznawanie ich za wypowiedzi formułowane bez koniecznego - zdaniem większości - doświadczenia praktycznego i rzeczywistej znajomości warsztatu historyka. Zdaję sobie sprawę, że nie dotyczy to

${ }^{16}$ Warto przypomnieć opinię Andrzeja Malewskiego i Jerzego Topolskiego, Studia $z$ metodologii historii, Warszawa 1960, s. 6: „najbardziej nawet przedmiotowo nastawionemu i niechętnemu refleksji nad nauką specjaliście trudno jest powstrzymać się od uwag o charakterze metodologicznym. Uwag takich w literaturze historycznej spotyka bardzo dużo, zwłaszcza przy ocenie prac innych autorów. Zarzuty o charakterze metodologicznym dotyczące sposobu stawiania zagadnień, sposobu ustalania faktów, sposobu selekcji faktów, sposobu wyjaśniania czy sposobu oceny spotyka się bodaj częściej aniżeli zarzut fałszywości wygłaszanych twierdzeń".

${ }^{17}$ Nie wszystkie zagadnienia związane z metodologią historii wymagają opanowania umiejętności badawczych wymaganych od historyka, ale ich brak zdecydowanie ogranicza zakres sensownej refleksji metodologicznej. 
wszystkich badaczy, którzy w swojej pracy zajmują się również metodologią historii, gdyż ci mogliby uważać się za pokrzywdzonych powyższym stwierdzeniem, ale sądzę, że akurat ta grupa również zauważa zarysowaną wyżej tendencję u wielu swoich koleżanek/kolegów po fachu. Warto przytoczyć po raz drugi opinię klasyków polskiej metodologii historii Andrzeja Malewskiego i Jerzego Topolskiego: ,uprawianie empirycznej metodologii historii wymaga zarówno znajomości dorobku ogólnej metodologii nauk, jak i ścisłego kontaktu z pracą badawczą historyków"18.

Dociekania, co jest miarą merytorycznej dyskusji, zasługują na osobną rozprawę. Jednak odnosząc się do mojej polemiki z Autorką, sądzę, że wystarczy, by moje opinie o jej książce były uznane za merytoryczne, o ile dotyczą problemów podejmowanych w jej książce oraz są wystarczająco uzasadnione. Zatem od recenzenta nie należy wymagać napisania drugiej, lepszej pracy na ten sam temat - jak chętnie ucieka się do tego argumentu wielu krytykowanych autorów - ale należy oczekiwać wyłożenia weryfikowalnego uzasadnienia dla swoich krytycznych (jak i pochlebnych) sądów. Zatem autorzy recenzji podają obszerną argumentację albo - co z powodu szczupłości miejsca czynią najczęściej - swoje wątpliwości jedynie sygnalizują i czytelnika odsyłają do literatury przedmiotu, w której ta argumentacja, którą podzielają, jest przedstawiona szerzej. Metodą Autorki jest prowadzenie polemiki ze mną tak, jakbym wszystkie moje opinie znajdujące się w moim tekście po raz pierwszy sam sformułował i światu tu obwieścił. Być może dla Autorki rzeczywiście część z cytowanych przeze mnie za literaturą poglądów brzmi jak nowość. Tymczasem wszystkie moje uwagi oddają pewien stan badań i do niego się odnoszę, odsyłając w przypisach do literatury, oraz porównuję z tym, co Autorka napisała. K. Polasik-Wrzosek ma przecież prawo nie zgadzać się z tymi opiniami, wyrażanymi nawet przez uznane autorytety, może podać własną argumentację, ale w swojej odpowiedzi tego nie robi.

Czytelnik może się przekonać, że sześcioarkuszową monografię Autorka napisała na podstawie 54 prac, ja w moim tekście (2 arkusze) przywołałem 90 prac. W niewiele krótszej odpowiedzi Autorka podpiera swoje twierdzenia 6 pracami, ale konsekwentnie ignoruje stan badań, na który się powołuję, udając, że krytyczne uwagi wobec jej książki wygłaszam w oderwaniu od literatury przedmiotu i poglądów innych badaczy. Sądzę nawet, że w części nie zapoznała się z cytowaną przeze mnie literaturą, w przeciwnym razie miarkowałaby swój całkowity sprzeciw.

Właśnie niewielką orientację w literaturze uznałem w konkluzji za podstawową przyczynę niepowodzenia badawczego Autorki. Przyznaję rację

${ }^{18}$ A. Malewski, H. Topolski, op. cit., s. 5. 
K. Polasik-Wrzosek, gdy ta pisze, iż „żenująca jest praktyka krytykowania z użyciem zwrotów w rodzaju: «autorka widać nie wie...», «autorka nie zna zapewne...» [zawsze Autorka pisałem dużą literą - D. A. S.]" (s. 342), ale jest to żenujące przede wszystkim dla autora omówienia, gdy musi zwracać uwagę na błędy podstawowe, przede wszystkim świadczące o braku przygotowania warsztatowego do zajmowania się konkretnym problemem. Ale co ma zrobić recenzent, gdy autor analizowanego tekstu po prostu nie zna podstawowej literatury bezpośrednio dotyczącej badanego zagadnienia? Ma udawać, że tego nie widzi i skutków nie dostrzega, zwłaszcza, gdy owe braki rzutują na ujęcie problemu, jak ma to miejsce w przypadku omawianej książki? Zdaniem K. Polasik-Wrzosek nie widzę różnicy między sytuacją „zna, ale nie cytuje” a „nie cytuje, bo nie zna” (s.342 n.). Autorka chce zasugerować, że literaturę zna, ale z różnych powodów na nią się nie powołuje. Dalej wyprowadza zgodnie z przyjętą metodą wnioski prowadzące do absurdalnego rezultatu: „cytuj wszystko bez względu na okoliczności” (s. 343). Temu samemu ma służyć zasugerowanie, że skoro ja nie cytuję innych prac Le Roy Laduriego i Ginzburga, to można mi zarzucić, że ich nie znam. Trzymajmy się faktów. Autorka poza książką Ginzburga - przypomnę, że będącą przedmiotem jej szczególnego zainteresowania - przywołuje tylko jedną jego inną pracę.Ja w swojej recenzji odwołuję się do 7 innych prac Ginzburga, które wiążą się z tematem książki Autorki, nie mówiąc o 6 innych omawiających metodę historyczną Ginzburga czy jego koncepcje historiograficzne. W przypadku książki Le Roy Laduriego te dysproporcje są znacznie większe. W obu przypadkach nie da się uzasadnić tej nieobecności tym, że Autorka je „zna, ale nie cytuje, bo nie są tego warte”, ani że „zna, ale nie cytuje”, bo jak wykazałem, jej nieznajomość wpłynęła na to, co Autorka o obu pracach napisała. Innymi słowy - nawiązując do retoryki Autorki - nie cytowała, bo były to prace jej nieznane.

Niejako w rewanżu Autorka stwierdziła, ,iż łatwo wskazać elementarne prace z obszaru teorii poznania historycznego, których przeczytanie ze zrozumieniem mogłoby spowodować, że ilość niedorzecznych sądów, jakie wypowiada Sikorski, uległaby zmniejszeniu" (s. 343). Może Autorka ma rację, trudno mi przesądzać, bo poza gołosłownie wygłoszoną opinią nie znam jej argumentacji. Jednak narzuca się pytanie, dlaczego kilkoma przypisami z literaturą, autorytetem autorów tych prac i na podstawie ich argumentacji, nie stara się choćby na kilku przykładach dowieść owych niedorzeczności? Przecież taka forma dyskusji jest jak najbardziej pożądana - formułujemy zarzut (tu mamy tylko mowę o „niedorzecznych sądach” bez wskazania konkretów) i cytując uznaną literaturę (tu nie cytuje), która naszą krytykę wspiera, ujawniamy owe bzdury. Jednak K. Polasik-Wrzosek wybrała inną meto- 
dę dla całego swojego tekstu, którą można zrekonstruować następująco: twierdzi, że jest wiele bzdur, ale w ich natłoku (tu: w mojej recenzji), nie mogąc się odnieść do wszystkich, nie pokazuje tego na kilku przykładach (nawet na jednym), które by uwiarygodniły jej zarzuty. Czytelnik ma uwierzyć na słowo.

Autorka zarzuca mi stosowanie pewnego „zabiegu retorycznego: najpierw imputuje się krytykowanemu jakiś pogląd, a następnie ironizuje na jego temat” (s. 332), który określiła jako „wydziwianie”. Przypisywaną mi praktykę ilustruje trzema przykładami. Pierwszy dotyczy mojej opinii, że „czytelnik przywiązany do tradycyjnej historiografii odetchnie z ulgą, gdy dowie się, że «moje [tzn.K.P.-W.] analizy zjawiska antropologizowania historii [- - ] dowodzą, że mimo tak przemożnego wtargnięcia problematyki antropologicznej do historii, ta ostatnia nie przestała nią być»"(s. 486), która w dalszej części jest przedmiotem ironicznych uwag K. Polasik-Wrzosek zbudowanych wokół nieporozumienia wynikającego z faktu, że Autorka nie zrozumiała tego, co przeczytała! Mowa jest o historykach nieufnych wobec nowości w historiografii bądź słabo zorientowanych w antropologii historycznej (od nich zacząłem niemal w pierwszym zdaniu), którzy - jak sądzę - po lekturze książki K.Polasik-Wrzosek odetchną z ulgą, że antropologia historii to ciągle jednak historia, a więc zostaje jeszcze pole do dalszej dyskusji o miejscu antropologii historycznej w badaniach historycznych. Nie opisuję tu swojego stanu, jak ironizuje Autorka, i rzekomo mojego niepokoju („konserwatywnego zatroskania”) o tradycyjną historiografię etc. Po prostu nie ja się kryję pod sformułowaniem „czytelnik przywiązany do tradycyjnej historiografii", gdyż cały tekst jest napisany w pierwszej osobie i w takim trybie formułuję swoje opinie.

Drugim przykładem „wydziwiania” mają być moje uwagi (s. 493 n.) dotyczące analogii między obserwacją uczestniczącą jako jedną z metod badań antropologicznych a „sytuacją badawczą, w jakiej znajduje się historyk o temperamencie antropologicznym w obliczu korzystania ze źródła, jakim są akta inkwizycyjne" (s. 338). Autorka pokpiwa z mojego stwierdzenia, że metoda uczestnicząca nie znajduje zastosowania w antropologii historycznej, bo jej istotą jest uczestniczenie badacza w badanej kulturze, swoim zwyczajem próbując sprowadzić tę uwagę do absurdu, tzn. sugerując, że mogłem sądzić, iż K. Polasik-Wrzosek, propagując zastosowanie obserwacji uczestniczącej w antropologii historycznej, proponuje przeniesienie się w czasie. Autorka dodaje, że „na stronach 52-58 mojej książki przytaczam prominentne opinie wzmacniające moją tezę o analogii między badaniem terenowym/obserwacją uczestniczącą" a symulowaną sytuacją historyka, gdy ten „stawia źródła «w ogniu pytań» o proweniencji antropologicznej" (s. 339, przyp. 20). Trzymajmy się zatem faktów. W żadnej z prac pięciu 
badaczy, na których się Autorka powołuje w książce (s. 52-58), nie znajdziemy bezpośrednich odniesień do obserwacji uczestniczącej (nie każda uwaga dotycząca badań terenowych wiąże się z obserwacją uczestniczącą), natomiast autorzy trzech z nich (Clifford Geertz, Michael Herzfeld i James Clifford) w innych pracach jednoznacznie negatywnie wypowiadali się o symulowaniu pracy antropologa przez historyka. J. Clifford wręcz poświęcił obszerną recenzję książce Le Roy Laduriego, w której jako antropolog oświadczył, że nie znalazł w niej antropologii! Jego zdaniem jedynie sama książka i środowisko intelektualne, w której powstała, są interesującym obiektem zainteresowań antropologa ${ }^{19}$. Herzfeld w ogóle podważa wartość samej metody ${ }^{20}$, Geertz zaś pokpiwa z Le Roy Laduriego próbującego udawać antropologa ${ }^{21}$. Zastrzeżenia co do możliwości symulowania obserwacji uczestniczącej w badaniach historycznych nie są moim wymysłem, jak sugeruje Autorka. Wystarczyłoby zapoznać się z cytowaną przeze mnie literaturą (s. 504, przyp. 52) ${ }^{22}$.

Po raz trzeci „wydziwiam”, zarzucając (gdzie?) ponoć Autorce, że „zakłada bezwzględną wiarygodność tzw. bezpośrednich świadków" (s. 339). Jest wręcz przeciwnie; mój wywód w tej sprawie (s. 493 n.) dotyczył przypisywania przez nią właśnie tego poglądu „tradycyjnym” historykom, co mija się z prawdą. Dla ścisłości K. Polasik-Wrzosek napisała: „w metodyce tradycyjnego badania historycznego [- - ] na dobre zadomowiła się idea bezpośredniego świadka. Ów świadek stanowi dla wielu historyków gwarancję wiarygodności, jest czymś w rodzaju nośnika «prawdy» o przeszłości” (s. 57). Stwierdzenie to jest po prostu niezgodne z „metodyką tradycyjnego badania historycznego", o czym wie każdy historyk znający tę metodykę, który w trakcie własnych badań miał powody, żeby zakwestionować na etapie krytyki źródła wartość relacji bezpośrednich świadków.

Wszystkie trzy przykłady pokazują, że moje „wydziwianie” powstało jedynie w myślach Autorki, która niedokładnie czytała mój tekst albo - co wydaje mi się bliższe prawdy - po prostu przyjęła taką taktykę polemiki.

Jednak opisana przez nią praktyka jak ulał pasuje do tej stosowanej przez Autorkę wobec mojego tekstu. Jedną z głównych strategii „dyskusji” przyjętej przez Autorkę jest wywarcie na czytelniku wrażenia, że

19 J. Clifford, Naming Names, „Canto” 3, 1979, 1, s. 142-153; ogólniejsze uwagi o obserwacji uczestniczącej idem, On Ethnographic Authority, „Representations” 1, 1983, 2, s. $118-146$.

${ }^{20}$ M. Herzfeld, Anthropology through the Looking-Glass, Cambridge 1987, s. 16, 28 nn., 90.

${ }^{21}$ C. Geertz, Dzieło iżycie. Antropolog jako autor, Warszawa 2000 (oryg. ang. 1988), s. 194.

${ }^{22}$ Dodać można wielokrotnie wznawiane podręcznikowe ujęcie J.P. Spradley, Participant Observation, New York 1980 oraz D. L. Jorgensen, Participant Observation: A Methodology for Human Studies, Newbury Park 1989. 
moje wymogi jako recenzenta są tak wyśrubowane, że aż absurdalne, lub że poglądy, które głoszę, są absurdalne same w sobie albo ich konsekwencje prowadzą do absurdów, co ma dowieść absurdalności samych zarzutów. Nie chodzi mi o to, że nie można posługiwać się taką argumentacją, wręcz przeciwnie, wykazanie, że czyjeś poglądy w konsekwencji prowadzą do absurdów, jest bardzo dobrym sposobem ujawniającym błędy logiczne w ich formułowaniu. Tymczasem K. Polasik-Wrzosek zbija w ten sposób rzekomo moje poglądy, które w rzeczywistości sama skonstruowała i je mi imputuje. Zdarza się, że - najczęściej w zapędzie polemicznym - coś źle zrozumiemy i przypisujemy polemiście nie to, co głosi, ale to, co nam się wydaje, że głosi, bo źle zrozumieliśmy, niedokładnie przeczytaliśmy etc. Niestety nie mam powodu sądzić, że chodzi tu o tego rodzaju pomyłkę, gdyż jest to zabieg nagminnie stosowany przez Autorkę w całym tekście, co wyklucza przypadkowość. Zapewne Autorka liczy na to - i w części pewnie słusznie - że czytelnik będzie jej rekonstruowane „moje” poglądy brał rzeczywiście za moje, nie podejrzewając, że autor tekstu może dopuszczać się jawnej manipulacji. Czytelnik nie będzie konfrontował jej „moich” poglądów z moim tekstem i tam rzeczywiście wypowiedzianymi poglądami, tym bardziej że nawet gdyby chciał, to napotka podstawową trudność - Autorka nie wskazuje stron, na których rzekomo owe poglądy wyraziłem ${ }^{23}$. Rekonstruowane przez Autorkę „moje” poglądy nie tylko nie zostały wyrażone wprost, ale i nie wynikają z moich jakichś innych, rzeczywiście sformułowanych przeze mnie wypowiedzi, chociaż Autorka stara się sprawić takie wrażenie, jakby stanowiły ich logiczną konsekwencję.

Nie mogę oczekiwać od czytelnika, że będzie za każdym razem, tylko po to, by zweryfikować trafność słów Autorki, uważnie wertował mój tekst w poszukiwaniu przypisywanego mi poglądu i że będzie w stanie bez poważniejszego zaangażowania się ujawnić ową - ujmując to łagodnie - kompromitującą Autorkę praktykę. Jedyne, co mogę zrobić, to pokazać przykłady obnażające te zbiegi.

Stosując tę metodę, K. Polasik-Wrzosek sugeruje, że rzekomo żądam od niej (gdzie?), aby sprawdziła, „czy Le Roy Ladurie właściwie interpretuje źródło" (s. 334), ponoć wymagam (gdzie?), żeby weszła w buty mediewisty, i to do tego specjalisty od trzynastowiecznej Langwedocji oraz „odczytała weryfikująco owo źródło, z którego korzystał Le Roy Ladurie” (s. 334). Nawet gdyby Autorka była historykiem, nawet gdyby była mediewistą, to bym

${ }^{23}$ Odnośniki do stron są wyłącznie przy fragmentach cytowanych z mego tekstu, ale te cytaty przemieszane z poglądami mi imputowanymi mają zapewne wzmocnić wiarygodność tych ostatnich. 
takich wymogów nie stawiał, gdyż sam jako mediewista nie posiadam wystarczających kompetencji, by bez uprzedniego przygotowania móc samodzielnie poruszać się $\mathrm{w}$ tej problematyce, więc jakbym mógł wymagać tego od niemediewisty (a tym bardziej - jak się okazało - niehistoryka). Przyznaję, że jako mediewiście znacznie łatwiej jest mi ocenić dyskusję wokół książki Le Roy Laduriego. Natomiast praca Ginzburga wychodzi chronologicznie poza obszar moich zainteresowań naukowych, ale nie znaczy to, że nie mogę wyważyć wartości argumentów przytaczanych w polemikach, które ta książka wywołała. Skargi K. Polasik-Wrzosek w tej sprawie mają osłabić jeden z moich głównych zarzutów wobec jej książki, że Autorka nie zadała sobie trudu zapoznania się z opiniami specjalistów, których kompetencje pozwalają im na krytyczne ustosunkowanie się zarówno do książki o Montaillou, jak i pracy Ginzburga. Sam w recenzji wytykałem innym, ale też sobie (s. 500, przyp. 45), że książka o Montaillou była chwalona na wyrost, bez znajomości rzeczy, bez zapoznania się z krytycznymi opiniami specjalistów bądź wskutek ignorowania tych ostatnich. Nadal uważam, że Autorka, czyniąc z tych dwóch książek przedmiot swojej szczególnej uwagi, powinna była zapoznać się ze stanem dyskusji historiograficznej - ani mniej, ani więcej. To był mój jedyny w tej sprawie postulat (s. 502).

Ponadto podtrzymuję moją opinię, że naprawdę trudno znaleźć usprawiedliwienie dla braku jakiegokolwiek zaciekawienia Autorki - nawet jako metodologa - specyficznymi źródłami, które były podstawą obu dzieł, skoro są one dostępne w tłumaczeniach na język nowożytny, a w przypadku zapisu przesłuchań Menocchia wydawca zamieścił obszerny komentarz krytyczny sposobu wykorzystania tego źródła przez Ginzburga. Jak Autorka wyobraża sobie prowadzenie ,analiz metodologicznych" bez uwzględnienia stosunku autorów obu analizowanych książek do ich empirii - tego w swojej replice nie wyjaśnia. Tym bardziej że najpoważniejsze zarzuty innych historyków - zapewne te, jeśli mogę sobie pozwolić na odrobinę ironii, które Autorka „zna, ale nie uznaje”dotyczą właśnie sposobu obchodzenia się ze źródłem, zwłaszcza przez Le Roy Laduriego. Doprawdy dziwię się, że Autorka obstaje przy tym, iż porównanie, jak mają się owe zapisy źródłowe do wizji kreowanej przez „mistrzów antropologii historycznej” w stosunku do „nieantropologicznych" ujęć tego samego problemu i opinii „tradycyjnych” historyków wypowiadających się w tej sprawie, nic nie wniesie. Wskazywałem Autorce, że istnieje całościowa analiza społeczeństwa Montaillou napisana przez Matthiasa Benada w 1990 r. z wykorzystaniem tego samego źródła. Czyż Autorka rzeczywiście chce utrzymywać, że analiza porównawcza obu monografii o Montaillou nie byłaby niezbędna ze względu na możliwość uchwycenia poszukiwanej differentia specifica ,antropologizacji” do- 
konanej - jej zdaniem - przez Le Roy Laduriego w stosunku do ujęcia „tradycyjnego” Benada? Czy też jest to kolejna lektura, którą Autorka „zna, ale nie uznaje"?

Również nie sądzę (jeśli tak, to gdzie?), że metodologia historii musi „ustalać w trybie kontrolnym, czy ta ostatnia [historia - D. A.S.] dochodzi do prawdy, czy nie" (s. 330), gdyż zadaniem metodologii jest badanie, jak historyk dochodzi do swojej wiedzy o przeszłości, jakie w tym celu stosuje procedury, niezależnie od tego, czy jako rezultat dociekań przyjmuje się jakąś prawdę historyczną, a jeśli tak, to jak filozoficznie umocowaną, czy też obywa się bez niej.Żeby móc poznać sposoby wnioskowania, metodolog musi analizować procedury, którymi posługuje się historyk, pozyskując ową wiedzę, także te odnoszące się do podstawy źródłowej.

W polemice Autorka kpiąco zastanawia się, co dało mi asumpt do twierdzenia, że „antropolodzy historyczni nie wypracowali ani nie praktykują innej metody badań historycznych na poziomie źródłowym niż ta, która jest uważana za standardową” (s. 333). Stwierdza, że „teza ta jest sprzeczna ze zdecydowaną większością analiz historiograficznych ostatnich 35 lat" (s. 333). Odpowiedź jest prosta: taki wniosek nasuwa się po analizie metod badań źródłowych, jakie uchwytne są nie tylko w książkach Le Roy Laduriego i Ginzburga, ale również w pracach innych historyków, których prace bywają zaliczane do antropologii historycznej. Ponadto w żadnym tekście teoretycznym dotyczącym antropologii historycznej nie znalazłem nawet namiastki takiego zarysu metod źródłoznawczych, innych zasad krytyki źródeł, które miałyby być charakterystyczne dla antropologii historycznej, a odbiegałby od powszechnie praktykowanych. Warto natomiast powyższe pytanie zwrócić w stronę pytającego, tym bardziej że we wstępie K. Polasik-Wrzosek stwierdza (s. 24, 26), ale nigdzie nie uszczegóławia, że antropologia historyczna wymaga rewizji podejścia do źródła, więc problem miejsca źródła w analizie metodologicznej dostrzega, ale nie potrafi go poddać analizie, uciekając się - na co zwracałem uwagę (s. 501 n.) - do kilku zaledwie ogólników. Zatem skoro Autorka postuluje odmienność metod źródłoznawczych rzekomo ustaloną dla antropologii historycznej już 35 lat temu, to dlaczego nie poparła tego żadnym przykładem ani w swojej książce, ani w polemice? Pokazanie na konkretnym przykładzie, że nie jest tak, jak ja twierdzę, ale tak, jak postuluje $\mathrm{Au}-$ torka, zamknęłoby dyskusję.

Ponieważ jeszcze nie wymyślono badań historycznych, które nie wynikałyby ze źródeł, analiza ich miejsca i roli w poznaniu historycznym jest niezbędna. Ten etap stanowi również przedmiot namysłu metodologa historii. Zatem metodolog musi umieć ocenić przesłanki epistemologiczne procedur stosowanych przez historyków, a przy większym zaangażowaniu 
ze swojej strony (i znajomości rzeczy) także konkretnej pracy historycznej, zwłaszcza wówczas, gdy za przedmiot swoich analiz z rozmysłem bierze konkretne prace historyków, jak uczyniła to K. Polasik-Wrzosek. Niestety, pogląd Autorki w tej sprawie nie jest odosobniony. Bardzo często analizy metodologiczne prowadzone przez badaczy określających się jako metodolodzy historii zatrzymują się na pewnym etapie prowadzonych analiz. Dość łatwo można wskazać konkretną przeszkodę - byłaby nią konieczność wykazania się przynajmniej podobną, a niekiedy nieco większą wiedzą o badanym przedmiocie w analizowanej pracy niż jej autor. Ponieważ metodolodzy zazwyczaj zajmują się pracami, których konkretny przedmiot jest im obcy, nie posiadają żadnej dodatkowej wiedzy wykraczającej poza tą deklarowaną przez autora analizowanego dzieła. $Z$ tego powodu bardzo szybko wyłącznie „metodologicznie ukierunkowany recenzent” przyjmuje punkt widzenia na problem, jaki prezentuje autor analizowanego dzieła. Jeśli jest on $-\mathrm{z}$ różnych powodów - wystarczająco atrakcyjny, pracę traktuje się za wzorcową. Jeżeli nawet pojawiają się głosy krytyczne ze strony historyków mających merytoryczne kompetencje w danym zagadnieniu, to są po prostu ignorowane ${ }^{24}$. Ten ostatni fakt wynika z braku kwalifikacji pozwalających ocenić dyskusję toczoną przez specjalistów wokół analizowanej metodologicznie pracy przez badaczy wyspecjalizowanych wyłącznie w metodologii historii.

Ponoć zarzucam Autorce, że nie realizuje ona mojego planu książki (s. 330), który miałbym w recenzji forsować. Zarzut jest gołosłowny, gdyż w moim tekście w żadnym miejscu nie składam własnych propozycji ujęcia podejmowanego przez Autorkę problemu. Wskazywania przeze mnie luk w jej wywodach - robię to zawsze z odesłaniem do literatury przedmiotu - nie należy utożsamiać z forsowaniem jakiejś własnej wizji problemu. Pewnie K. Polasik-Wrzosek chce sprawić wrażenie na czytelniku, że wymagam od niej jako Autorki napisania takiej książki o antropologii historycznej, jaką sam bym napisał, a tym samym każdą inną pracę w tym i jej - oceniam przez pryzmat tej mojej nienapisanej książki. Jednak łatwo można zauważyć, że odnoszę się wyłącznie do jej książki i oceniam ją na tle dyskusji historiograficznej dotyczącej przedmiotu jej badań. Tak widzę rolę recenzenta.

Podobnie gołosłowne są skargi Autorki, że wymagam od niej napisania monografii Montaillou oraz że żądam, by zajęła się całościowo pisarstwem Le Roy Laduriego. $Z$ drugiej strony zarzuca mi, iż sam nie

${ }^{24} \mathrm{~W}$ taki sposób potraktowany został jedyny tekst krytyczny wobec książki Le Roy Laduriego, o którym wspomina Autorka - zbyła go, nawet nie czytając (s. 104 oraz moje uwagi s.495). 
znam innych jego książek - bo ich nie cytuję - „które w kontekście jego [tzn. mojej] całościowej oceny Montaillou wydają się nie do pominięcia" (s. 343). Z ostatnią opinią Autorki całkowicie się zgadzam: jeśli „klasyk antropologii historycznej [tzn. Le Roy Ladurie] obok Carla Ginzburga [--] to bohaterowie moich [tzn. K.P.-W.] analiz metodologicznych" (s. 9 n.), to owe analizy metodologiczne powinny uwzględniać również inne prace owych Autorów oraz ich wypowiedzi metodologiczne znajdujące się w innych pracach, tym bardziej że Ginzburg opublikował kilka tekstów na ten temat (s. 506, przyp. 57). Jednakże Autorka tego wszystkiego w swoich ,analizach metodologicznych" właśnie nie robi! Śmiem twierdzić, że dlatego, iż tej dyskusji i tych prac nie zna. Wytykam te braki, odsyłając do dyskusji metodologicznej wokół wspomnianych dwóch dzieł i wskazując na publikacje, w których Ginzburg rozwija swoje poglądy teoretyczne. Sięgnięcie przez Autorkę do Le Carnaval de Romans, książki wydanej w trzy lata po Montaillou, pozwoliłoby lepiej uchwycić inspiracje antropologiczne Le Roy Laduriego, gdyż tu odwrotnie niż w Montaillou - ujawnia on swoje źródła inspiracji ${ }^{25}$. Ale tego Autorka nie zrobiła.

Jednym z chwytów erystycznych jest odwrócenie uwagi publiczności od głównego problemu przez skupienie uwagi (rozmyślnie przesadnej) na jakichś zasadnych bądź bezzasadnych, czy - jak ma to miejsce w tym przypadku - wymyślonych drobiazgach, które zostają wyolbrzymione. K. Polasik-Wrzosek w dwóch wariacjach (por. s. 333, 335) skupiła się na użytym przeze mnie słowie „powinien” (,praca samej Karoliny Polasik powinna zostać poddana zwykłemu osądowi historyka, wedle kryteriów i zasad typowych dla metody i krytyki historycznej", s. 486). Autorka ignoruje fakt, że tak często używane w polszczyźnie słowo ma kilka znaczeń. Obok sensu wyrażającego przymus lub konieczność (to sugeruje Autorka) wyraża także sens oczekiwania. Ten ostatni uwydatnia się zwłaszcza, gdy występuje z orzeczeniem (w sensie, iż oczekuje się, że zajdzie czynność wyrażona orzeczeniem $)^{26}$. Autorka wybrała jednak „zabawę” słówkami, licząc, że czytelnik nie zauważy tej manipulacji. Podobne gry uprawia innymi słowami

${ }^{25}$ André Burguière (The Annales School. An Intellectual History, Ithaca 2009 (oryg. franc. 2006), s. 142 n.) określił Le Carnaval de Romans jako „remake of Montaillou”.

${ }^{26}$ Słownik języka polskiego PWN (wydanie na CD) sprawę wyjaśnia: słowo „powinien” - „w połączeniu z podmiotem nieosobowym wskazuje na konieczność spełniania pewnego warunku, odpowiadania pewnym wymaganiom, oczekiwaniom wyrażonym w orzeczeniu", np. zupa powinna być gorąca. Co znaczy, że nikt zupy nie zmusi do tego, żeby była gorąca, ale zamawiając ją w restauracji, powszechnie się oczekuje, że będzie. 
z powyższego cytatu: „zwykły” (s. 334) ${ }^{27}$, ,typowy” (s. 334, przyp. 10) oraz „deklaratywny” (s. 346), nie mówiąc już o nawiązaniu do molierowskiego Jourdaina (s. 347 n.). Wystarczy sięgnąć po słownik języka polskiego.

Wyciągnięcie wniosków z mojej dyskusji nad książką i polemiką K. Polasik-Wrzosek, pozostawiam czytelnikowi. Sądzę, że kwestie merytoryczne zostały przeze mnie w obu tekstach wystarczająco jasno wyłożone, i ufam, że czytelnik uprzedzony przeze mnie co do metody polemiki wybranej przez Karolinę Polasik-Wrzosek odczyta jej tekst tak, jak ja go przyjmuję - jako próbę zatuszowania przez Autorkę własnej niekompetencji.

${ }^{27}$ Słownikowe znacznie słowa „zwykły”: ,zgodny ze zwyczajem, z przeciętną normą, taki jak zawsze, powszedni, pospolity", a zatem chodzi o krytykę historyczną przeprowadzoną zgodnie ze zwyczajem i tak, jak się praktykuje. 